Article

\title{
Can Public Procurement Requirements for Railway Transport Promote Economic and Social Sustainability in South Africa?
}

\author{
David Fourie $^{1, *(\mathbb{D})}$ and Cornel Malan ${ }^{2} \mathbb{D}$ \\ 1 School of Public Management and Administration, Faculty of Economics and Management Sciences, \\ University of Pretoria, Pretoria 0001, South Africa \\ 2 Independent Research Advisor, Privatebag X1007, Lyttelton 0140, South Africa; drcmalan@icloud.com \\ * Correspondence: prof.djfourie@up.ac.za; Tel.: +27-83-258-5273
}

Citation: Fourie, D.; Malan, C. Can Public Procurement Requirements for Railway Transport Promote Economic and Social Sustainability in South Africa? Sustainability 2021, 13, 11923. https://doi.org/10.3390/su132111923

Academic Editors:

Mayca Rubio-Gámez and

Fernando Moreno-Navarro

Received: 30 August 2021

Accepted: 22 October 2021

Published: 28 October 2021

Publisher's Note: MDPI stays neutral with regard to jurisdictional claims in published maps and institutional affiliations.

Copyright: (c) 2021 by the authors. Licensee MDPI, Basel, Switzerland. This article is an open access article distributed under the terms and conditions of the Creative Commons Attribution (CC BY) license (https:/ / creativecommons.org/licenses/by/ $4.0 /)$.

\begin{abstract}
When considering sustainability from a socioeconomic and environmental point, the South African public transport industry was not an integral part of such planning until the last decade. Various well-intended and well-defined public procurement and environmental regulatory policies and instruments were put in place over the years, however, they appear to be failing in achieving the goals of local job creation and alleviation of unemployment. This exploratory literature review study of various public documents, regulatory instruments, and review reports aims to evaluate current knowledge pertaining to the current level of sustainable transport from a life-cycle approach, in support of overall sustainable goals in South Africa. The research set out to assess the status of public procurement in the revitalising of public rail freight transport towards identifying areas of excellence that could be used to address under-performance in other areas. The documentary analysis found various areas where the public procurement policies within South Africa, which aims to promote local participation, are facing difficulties due to lack of access to modern technology as well as inadequate skills levels to be able to partake in the ventures. In exploring South African challenges and current solutions, the article recommends a holistic and integrated approach to provide for a sustained manufacturing and service supply stream within the local railway transport environment.
\end{abstract}

Keywords: public procurement; green transport; economic and social sustainability; railway life cycle management

\section{Introduction}

According to the Organisation for Economic Co-operation and Development (OECD) sustainable procurement can be described as "... a process whereby organisations (or national governments) meet their needs for goods, services, works and utilities in a way that achieves value for money on a whole life basis (.. ) whilst minimising damage to the environment" [1].

This definition highlights two particularly important themes, those being longevity of procurement and a move towards responding to the challenges of climate change. The transport sector of any developing country, as would be the case for South Africa (SA), is viewed as a vital component towards stimulating long-term economic growth as well as inclusive social development. At the same time, SA is also faced with the growing importance of moving towards sustainable or so-called "green" transport. All these aspirations are underpinned by the need to improve the economy of South Africa by means of an inclusive public procurement process which drivers locally owned and produced content. As such, the National Department of Transport (DoT) compiled a comprehensive strategy for the transport sector to make a substantial contribution to national economic development through a "people-centred approach that creates opportunity and stimulates growth" [2]. The National Department of Transport (DoT) in its 2017 Draft Revised White Paper on National Transport Policy acknowledges that sustainable transport practices receive are not given much consideration within transport policy in South Africa. South 
Africa therefore must adapt its transport policy view as part of the greater economic growth policies to be in line with environmentally sustainable transport development guidelines and requirements [3].

The paper focuses on the following two main aspects; firstly, on sustainable socioeconomic development through public procurement policy and practices; and secondly, on the ability to ensure sustainable transport life cycle management.

This article aims to evaluate the usefulness of public procurement as driver of the goals of sustainability, accountability, and advancement of economic and social development through the stimulation of localised manufacturing and servicer-provision. It explores the meaning of sustainable public procurement, as well as the rationale for green transport initiatives. In particular, the study focuses on the South Africa rail transport arena and evaluates the existing public procurement policy framework for the promotion of sustainable transport, including current challenges and opportunities for future growth of the industry.

\section{Methodology}

This paper presents a systematic literature review of the role of public procurement in rail transport in promoting economic and social sustainability in South Africa. In more detail, the systematic analysis of policy documents, current reports, and articles aims to contextualize and address the current gap in academic and sectorial knowledge [4] pertaining to the applicability and efficacy of South African Public procurement policy approaches towards instilling a sustainable impact on the socioeconomic development and growth using railway freight transport within the country. Research on public procurement frameworks and the rail transport life cycle aims to identify how the lawmaker intended to direct rail transport development projects towards creation of local economic empowerment, and in addition, to determine progress was made in this regard as well as to what degree the skills requirements can be met to make such projects sustainable.

Towards addressing the main research objective of evaluating the efficacy of the current South African public procurement policy approach as an instrument to drive the goals of sustainability, accountability, and promotion of economic and social development through the stimulation of localised manufacturing and servicer-provision in the rail freight transport sector, the research approach followed in this article is qualitative in nature, using unobtrusive research techniques to analyse the literature and documentary data obtained through a desktop study. Three unobtrusive research techniques that are nonreactive were utilised, namely, content, conceptual, and historical comparative analyses [5]. The descriptive article is based on data gathered through contextual considerations of numerous international and national public documents, scholarly literature, and government reports and policies.

As a research method, document analysis is acknowledged as a qualitative research method through which a research objective or question is answered by means of an indepth and systematic analysis [6] of various literary discussions and studies [7]. This notion builds on the thinking of earlier researchers such as Bowen (2009), who argued that research by means of document analysis, "is particularly applicable to qualitative case studies-intensive studies producing rich descriptions of a single phenomenon, event, organisation, or program" [8].

The findings in this article are the result of the review of 52 documents as part of 117 documents retrieved electronically. A broad-based search approach of documents that discussed aspects pertaining to transport policy, procurement, economic and social sustainability, railway life cycle management, and green transport was used based on various search strings which used a combination of terms such as sustainable transport, the role of public procurement to improve socioeconomic development, transport policy, and sustainability, as well as rail freight transport and sustainable procurement.

The initial search was conducted in May 2021 and returned 94 items. These documents varied from policy documents retrieved from various South African Governmental repositories, as well as official governmental reports, statistical publications, and discussion 
papers. In addition, documents pertaining to sustainability were retrieved from international entities such the United Nations and the OECD as well as conference papers and peer-reviewed articles published pertaining to the relevant key concepts used.

Based on an initial analysis of abstracts, findings, recommendations, and conclusions of the retrieved documents, 59 were not selected for further analysis, whilst 35 were selected for in-depth analysis. After a review of the initial article, an updated literature search, utilizing the same concepts, was conducted in September to early October 2021, which yielded an additional 23 documents. A similar initial check of the abstracts, findings, recommendations, and conclusions of the newly retrieved documents resulted in 17 documents added to the database. The Table 1 below provides insight into the inclusion and exclusion criteria applied [9].

Table 1. Inclusion and exclusion criteria for documentary review.

\begin{tabular}{|c|c|}
\hline Included & Excluded \\
\hline April 1994 to current date & Documents prior to April 1994 \\
\hline Full journal articles (peer reviewed) & Full journal articles (not peer reviewed) \\
\hline $\begin{array}{l}\text { Conference proceedings, presentations, } \\
\text { policy documents }\end{array}$ & $\begin{array}{l}\text { Blogs, commentaries, LinkedIn, and other } \\
\text { similar discussions etc. }\end{array}$ \\
\hline $\begin{array}{l}\text { Studies on railway, particularly freight } \\
\text { rail transport }\end{array}$ & $\begin{array}{l}\text { Studies on walking, cycling, automobiles, } \\
\text { airlines, or other modes of transport }\end{array}$ \\
\hline Focus on sustainability & $\begin{array}{l}\text { Focus on service delivery and } \\
\text { customer satisfaction }\end{array}$ \\
\hline Focus on public procurement/supply chain & Focus on private procurement/supply chain \\
\hline Critical reflection and analysis by author(s) & $\begin{array}{c}\text { Opinion/perception-based analysis } \\
\text { by author(s) }\end{array}$ \\
\hline Includes key concepts or similar wording & No mention of key concepts or similar wording \\
\hline
\end{tabular}

The process of data reduction took place on a continuous basis through a process of editing, segmenting, and summarising the unstructured data towards identifying constructs, themes, and conclusions. Tesch (1990) in [10] views this approach as "decontextualization and recontextualization, which result in a higher-level analysis". The material reported in the literature review and discussion sections is the result of a detailed content and contextual analysis of the information as per the various themes identified.

\section{Literature Review and Background to the Study}

\subsection{The Role of Transportation in Economic Development}

In general, market pull-and-push effects determine the development process of the railway transport system. These are influenced by economy and societal drivers as well as developments within technological processes. By balancing the two forces, policymakers aim to provide for greater efficiency, safer and sustainable railway systems, which are currently lagging in developing countries [11].

Economic growth is directly related to and dependant on positive movement in the labour market - negative movements such as in increase in the skills gap and less available jobs damage or negatively impact the growth trajectory of the economy. For that reason, sustainable infrastructure is a prerequisite for job creation. Investing in the local content for the upgrading and maintenance of transport systems will create jobs in the sector and also provide for a sustainable public transport system that is accessible and affordable to the vast majority of the population, which in turn will provide access to job opportunities for the unemployed in the absence of their own private vehicles. It will also provide for the opportunity for small, medium, and micro enterprises (SMMEs) to distribute their product via a much cheaper rail freight system throughout the country and even beyond the borders [12,13]. 
Railway transportation by means of well-designed and manufactured rolling stock (made up out of various types of locomotive and carriage/wagon configurations) provides for mass transportation of people and/or goods within cities or across the country, and even beyond, on a well-developed rail network infrastructure.

"Freight transport is absolutely essential to modem urban civilisation. The very concept of urbanisation requires a freight system to sustain it, since urbanisation means that large numbers of people are accumulated in areas remote from their sources of food, sources of raw materials for industry, markets for industrial products, and places to dispose of their waste. No urban area could exist without a massive, sustained, and reliable flow of goods to, from, and within it" [14].

\subsection{What Is Green Transport?}

Ever since the 1972 Stockholm Plan of Action, there was an increasing international focus on improving transportation systems, to address the ever-increasing demand for mass movements of people and goods, and also to find more "planet-friendly" approaches to do so [15].

Various definitions of Green Transport were found in the retrieved documentary data. One of the most prominent definitions is that of the United Nations Environment Programme (UNEP) which outlines Green Transport as transport that "supports environmental sustainability through, e.g., the protection of the global climate, ecosystems, public health, and natural resources. It also supports the other pillars of sustainable development, namely, economic (affordable, fair, and efficient transport that supports a sustainable competitive economy as well as balanced regional development and the creation of decent jobs) and social (e.g., allowing the basic access and development needs of individuals, companies and society to be met safely and in a manner consistent with human and ecosystem health, and promoting poverty reduction and equity within and between successive generations)." [16]. Green transport, also known as "sustainable transport, refers to modes of transportation that do not negatively impact the environment such as the case would be with emissions form the use of fossil fuels. Green transport modes rely on renewable energy sources such as biomass, hydroelectric wind, and solar energy, among others" [17].

Green transport can therefore be viewed as both the means to an end (sustainable objectives, actions, and resource application), and an envisaged end itself (the ultimate suitability goal) $[13,18]$. This view entails the requisite activities towards ensuring that the movement of goods and people become economically efficient, whilst also providing for equitable representation in line with the societal construct and lowest possible adverse impact on the environment [13], as per the Figure 1 below:
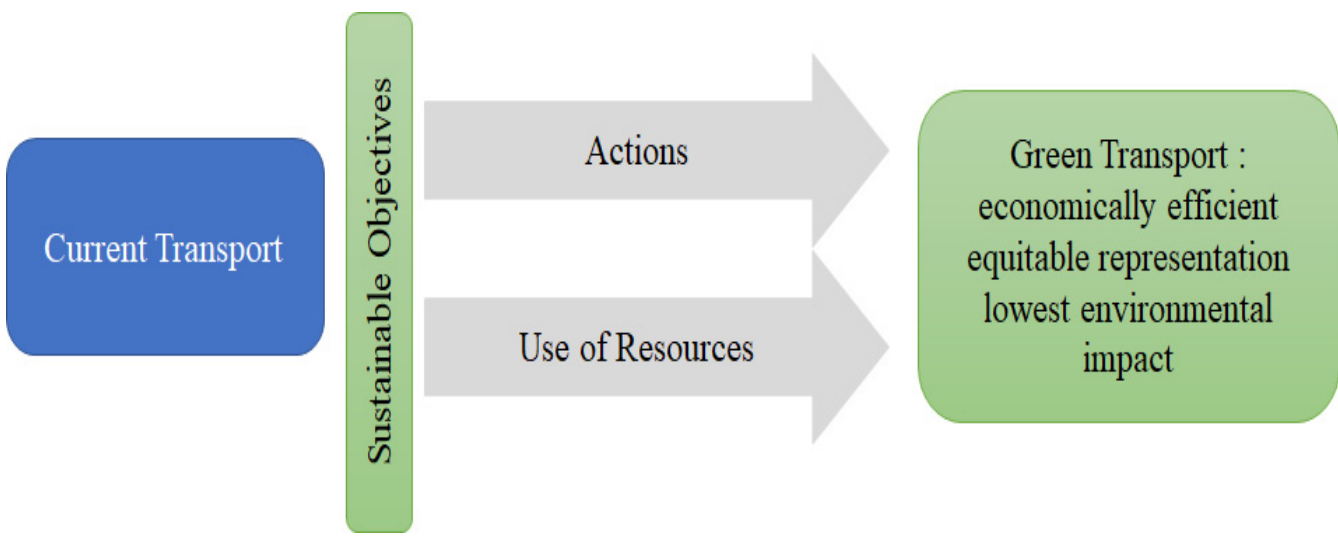

Figure 1. Sustainable actions towards sustainability goal. Authors adaption of [13]. 
"Successful delivery of the SDGs requires integrated transport governance and, in many cases, cross-sectoral collaboration. This is expected to contribute to yet another goal: SDG 17: Partnerships for the Goals. There are many challenges-including in energy, material use and business models - that offer opportunities for creative innovation by manufacturers, SMEs, academics, and public institutions. If they challenge the current status, they will respond to SDG 9: Industry, innovation and infrastructure" [19,20].

\subsection{Technological Developments}

From a sustainability point of view, technological developments should also aim at expanding the current market share of the railway industry. The true value of will be found in increasing the accessibility of a country's people and goods to movement to and from other geographic locations, which could have a potentially huge impact on the country's the competitiveness and economic growth [21].

Rolling stock is characterised by driving force of propulsion, territory, application (freight or passenger), speed, or even technology. The various types of design all have some key elements which could increase the construction unit cost and should also include design considerations for maintenance and operation factored into the planning [22].

Similar to discussion in other engineering-related areas or businesses, the Internet of Things, and more specifically, the Industrial Internet of Things as a topic, is receiving much attention within the railway industry. Research reveals that railway operators globally indicate in their annual reports and discussions as reported in the professional railway engineering media, the main area of interest quite predictably lies within the operation and maintenance space, to increase predictive maintenance activities and reduce the current high levels of unplanned maintenance activities. This turn leads towards improving availability and reducing failure on demand [22].

The focus on improved reliability and availability must also be viewed in the same context as the strive towards energy reduction, which is, first and foremost, an imperative in the conceptualisation and designing phases for new Rolling Stock. These technical targets for sustainable rolling stock are also coupled to a reduction in weight, mostly by means of the use lighter yet stronger manufacturing materials and design considerations [22].

\subsection{Life Cycle Approach}

Railway freight systems are complicated. The systems are known for their long lifespan and high costs of their infrastructure, but their vital role in the economy and society cannot be ignored. The long-term impact suggests following a long-term and systemic approach to avoid deviating from reaching the sustainability targets [2].

The rail industry in providing for transportation of goods and passengers, also involves the life-cycle maintenance, servicing, repair, overhaul, and testing of rolling stock (locomotives, wagons and coaches), signalling equipment, the railway infrastructure (perway, stations and overhead traction), and support services, as well as the operational control and management of resources including human resources and finances [23].

The life cycle of Rolling Stock from its design, construction, testing, and commissioning and maintenance of existing rolling stock requires of operators to consistently attempting to find a balance between highly specialised vehicles that are "fit for purpose", and can be built, operated and maintained in a cost-effective and sustainable manner over a long period of time [22].

Until recent times, the main methodology for decreasing the weakness of transport systems was to make gradual and small-scale changes and while this approach was effective in general, it does not provide for instability in the environment such as fundamental climate changes or large-scale deterioration of the society or the economy.

\subsection{South African Transport Subsector-Railway Transport}

The main companies in the South African rail transport subsector are Transnet SOC Ltd., Johannesburg, South Africa (freight), the Passenger Rail Agency South Africa (PRASA) 
(passengers) and the Gautrain-Bombela Consortium (passengers). Other medium and small-sized rail enterprises are active in the subsector at the ports (especially pertaining to shunting) and cross-border operations such as Swazirail, Botswana rail, and Caminhos de Ferro de Moçambique (CFM) [21], rail heritage societies such as Rovos Rail (private railway company that is based in Pretoria) and private rollingstock operated by surface railway operators on mines (unground transportation is managed by the mining entities and not viewed as railway transport in terms of the National Railway Safety regulator Act 16 of 2002 [24]). The network also comprises of local municipal sidings and service lines which link the national freight rail network to various private sidings for numerous operators in the agricultural, manufacturing, and petrochemical subsectors [23].

\subsection{Sustainable Development Agenda for South Africa}

All three spheres of government in South Africa are required to conduct development planning, culminating in the national Medium-Term Strategic Framework (MTSF), Provincial Growth and Development Strategies (PGDS) and the individual municipal Integrated Development Plans (IDP), to ensure effective service delivery to all the people of South Africa [24].

In addition, this development planning framework is also supported by the Spatial Development Frameworks (SDFs) at national, provincial, and local government levels, aimed at providing additional guidance to sustainable development. It is also important to note that the current MTSF 2019-2024 supports the overall guiding document of South Africa, the National Development Plan (NDP), and its objectives towards alleviating the triple challenge of unemployment, inequality, and poverty as a central approach to all initiatives towards transformation that supports the overall national development agenda [24,25].

The Table 2 below provides a summary of the main socioeconomic challenges and numeric targets for South Africa, as well as the policy source where such targets were proclaimed [26]. These regularity documents are discussed in more detail in later sections of the paper.

Table 2. South African socioeconomic challenges and targets.

\begin{tabular}{|c|c|c|c|}
\hline Focus Area & Theme & Numeric Target & Source \\
\hline \multirow[t]{4}{*}{$\begin{array}{l}\text { Socio-economic } \\
\text { development }\end{array}$} & Poverty & $\begin{array}{c}\text { Reduce poverty from } 39 \% \text { to } 0 \% \text { of the population } \\
\text { living below the national poverty line } \\
\text { (418 Rands per month/2009 prices) [26] } \\
\text { The MTSF 2019-2024 sets a target of reducing poverty, based on } \\
\text { the LBPL, to } 28 \% \text { by } 2024 \text { [26]. }\end{array}$ & $\begin{array}{l}\text { National Development } \\
\text { Plan (2012) } \\
\text { MTSF (2020) }\end{array}$ \\
\hline & Inequality & $\begin{array}{l}\text { Income inequality (as measured in Gini Coefficient) should } \\
\text { decrease from } 0.7 \text { to } 0.6 \text { by } 2030 \text { [26]. } \\
\text { MTSF 2019-2024 aims to lower South Africa's Gini Coefficient } \\
\text { to } 0.66 \text { by } 2024 \text { [26]. }\end{array}$ & $\begin{array}{l}\text { National Development } \\
\text { Plan (2012) } \\
\text { MTSF (2020) }\end{array}$ \\
\hline & Jobs & $\begin{array}{l}\text { Reduce unemployment from } 25 \% \text { percent } \\
\text { (in 2010) to } 15 \% \text { in } 2020 \text { [26]. } \\
\text { Create 300,000 jobs in the "Green economy" with } 80,000 \text { in } \\
\text { manufacturing and the rest in construction } \\
\text { and infrastructural development [26]. }\end{array}$ & New Growth path (2010) \\
\hline & GDP & $\begin{array}{c}2.7 \% \text { annual growth of GDP [26]. } \\
\text { GDP needed to grow significantly, from R2.9 trillion in } 2011 \text { to } \\
\text { R7.8 trillion in } 2030 \text { [26]. } \\
\text { Growth rate of } 2-3 \% \text { by } 2024 .\end{array}$ & $\begin{array}{l}\text { National Development } \\
\text { plan (2012) } \\
\text { MTSF (2020) }\end{array}$ \\
\hline
\end{tabular}


Table 2. Cont.

\begin{tabular}{|c|c|c|c|}
\hline Focus Area & Theme & Numeric Target & Source \\
\hline \multirow[t]{3}{*}{$\begin{array}{l}\text { Mitigation \& } \\
\text { energy security }\end{array}$} & $\begin{array}{l}\text { Emissions } \\
\text { reductions }\end{array}$ & $\begin{array}{l}\text { Reduce emission through mitigation actions by } 34 \% \text { by } 2020 \text {, } \\
\text { and } 42 \% \text { by } 2025 \text { [26]. } \\
\text { National GHG Emissions Trajectory Range projected to } 2050 \\
\text { following the peak (at } 583 \text { Megatons (109 kg) (Mt) CO2-eq and } \\
614 \text { Mt CO2-eq for } 2020 \text { and } 2025 \text { respectively) plateauing (for } \\
10 \text { years (2026-2035) between } 398 \text { and } 614 \mathrm{Mt} \mathrm{CO2-eq)} \mathrm{declining} \\
\text { in absolute terms (from } 2036 \text { to a range between } 212 \text { and } 428 \mathrm{Mt} \\
\text { CO2-eq [26]. }\end{array}$ & $\begin{array}{l}\text { National Climate } \\
\text { Change Response White } \\
\text { paper (2011) }\end{array}$ \\
\hline & $\begin{array}{l}\text { Renewable } \\
\text { energy }\end{array}$ & $\begin{array}{l}\text { 10,000 GWh ( } 0.8 \text { Mtoe) renewable energy contribution to final } \\
\text { energy consumption by } 2013 \text {, to be produced mainly from } \\
\text { biomass, wind, solar, and small-scale hydro initiatives [26]. }\end{array}$ & $\begin{array}{l}\text { White paper on } \\
\text { Renewable Energy } \\
\text { (2003) }\end{array}$ \\
\hline & $\begin{array}{l}\text { Overall energy } \\
\text { mix for } \\
\text { electricity }\end{array}$ & $\begin{array}{l}\text { 9.6 GW of nuclear; } 16.3 \mathrm{GW} \text { of coal; } 17.8 \mathrm{GW} \text { of renewables; } \\
\text { and } 8.9 \mathrm{GW} \text { other by } 2030 \text { [26]. }\end{array}$ & $\begin{array}{l}\text { Integrated Resource } \\
\text { Plan (2011) }\end{array}$ \\
\hline
\end{tabular}

Source: own compilation adapted from [26].

\section{Discussion}

\subsection{Leveraging Public Procurement to Support Industrialisation-A Procurement Regulatory Framework}

The term "public procurement" is normally understood to refer to the purchasing of goods and services by a governmental or state entity to fulfil various public functions. Even though the concept of value for money or "procurement on the best possible terms" is the primary factor of importance, governments were increasingly observed to use public procurement for the pursuit of secondary objectives such as social upliftment, sustainability, and equality and accordingly public policy which support public procurement has also broadened. Examples of recent expansion of policy focus includes the protection of the environment, while public procurement is used to stimulate innovation is also receiving mounting interest. The buying power of governments is increasingly being accepted as a "demand-side-oriented tool" that can influence and stimulate growth, innovation, and expansion [27].

The South African government's current levels of public procurement allow for this purchasing power to be leveraged to offer critical demand-side support to industry by:

- "Creating a repository of data on government procurement spending to allow evidencebased government-led product selection for designation;

- $\quad$ Aligning and enforcing procurement processes at all levels of government;

- Capacitating the South African Bureau of Standards (SABS) to ensure that it is able to conduct local content verifications;

- Collecting information on procurement spend across all levels of government to improve the targeting of public procurement as an industrial policy tool; and

- Monitoring and enforcing designations to ensure that they are being adhered to by all organs of the state" [28].

In terms of Section 217 of the Constitution of the Republic of South Africa Act 108 of 1996, when an organ of state in the national or local sphere of government, or any other institution identified in national legislation, contracts for goods or services, it must do so in accordance with a system which is fair, equitable, transparent, competitive, and cost-effective" [29]. The Constitution set the foundation for a new approach to public procurement by instituting guiding procurement principles for all public procurement processes. The Constitution further introduced Section 217 (2) and (3), which brought about the Preferential Procurement Policy Framework Act, Act Number 5 of 2000 and its regulations, in response to the imbalances created by the apartheid regime [28].

The Preferential Procurement Regulations 2011 were promulgated in June 2011, and shortly thereafter the Local Procurement Accord was signed between Government and its 
economic and social partners on 31 October 2011 towards promoting local manufacturers over importing suppliers of manufactured goods by establishing minimum thresholds for local content participation. In addition, the aim was to grow the very important SMMEs sector and protect existing local SMMEs who are manufacturers [30].

The 2011 Preferential Procurement Regulations introduced the National Industrial Participation Programme (NIPP), and also as alluded to in the previous section, announced the concept of selective participation in industrial development by the shielding or "ringfencing" of participation levels. This was done by means of various procurement instructions pertaining to Designated Sectors for Local Production and Content and very clearly illustrated the national government's commitment to industrialise our economy by using local content requirements in public procurement, as intended by Section 5 of the PPPFA. The 2011 Regulations were thus the vital legislative impetus towards inclusive economic growth and the associated social upliftment [30].

One such example is the 2012 National Treasury Instruction note entitled "Invitation and Evaluation of Bids based on a Stipulated Minimum Threshold for Local Production and Content for the Rail Rolling Stock Sector" [31]. This instruction note to all Accounting Officers and Accounting Authorities within the state indicates that the Department of Trade and Industry (DTI) stipulated the minimum local production and content threshold for classes within the Rail Rolling Stock sector.

The Table 3 below provides more detail in this regard [31]:

Table 3. Minimum threshold per classes of rolling stock [31].

\begin{tabular}{cc}
\hline Classes of Rail Rolling Stock & Stipulated Minimum Threshold \\
\hline Diesel locomotives & $55 \%$ \\
\hline Electric locomotives & $60 \%$ \\
\hline Electric Multiple Units (EMU) & $65 \%$ \\
\hline Wagons & $80 \%$ \\
\hline
\end{tabular}

The Preferential Procurement Regulations, 2017, Section 8 in support of the National Treasury Preferential Procurement Policy Framework Act, 2000, stipulates the following:

8.(1) "The Department of Trade and Industry may, in consultation with the National Treasury-

(a) designate a sector, subsector, or industry or product in accordance with national development and industrial policies for local production and content, where only locally produced services or goods or locally manufactured goods meet the stipulated minimum threshold for local production and content, taking into account economic and other relevant factors; and

(b) stipulate a minimum threshold for local production and content.

(2) An organ of state must, in the case of a designated sector, advertise the invitation to tender with a specific condition that only locally produced goods or locally manufactured goods, meeting the stipulated minimum threshold for local production and content, will be considered.

(3) The National Treasury must inform organs of state of any designation made in terms of regulation $8(1)$ through a circular.

(4) (a) If there is no designated sector, an organ of state may include, as a specific condition of the tender, that only locally produced services or goods or locally manufactured goods with a stipulated minimum threshold for local production and content will be considered.

(b) The threshold referred to in paragraph (a) must be in accordance with the standards determined by the Department of Trade and Industry in consultation with the National Treasury.

(5) A tender that fails to meet the minimum stipulated threshold for local production and content is an unacceptable tender" [32]. 
Over and above protecting the SA manufacturers, revised Preferential Procurement Regulations, which were promulgated by 23 January 2017 and became effective on 1 April 2017, sought to ensure an advantage to SMMEs, including co-operatives and township and rural businesses, by stipulating the so-called "prequalification and subcontracting criteria", thereby ensuring that high value government contracts are obliged to include local participation by means of specified "subcontracting" [33]. These Preferential procurement regulations of 2017 on local content empowers the DTI to elect and specifically provide for designated industries/sectors targets requiring a pre-determined percentage of "locally manufactured products that meet the stipulated minimum threshold for local content" [33].

The Figure 2 below provides insight into the various categories that were identified to date for such local content production/manufacturing.

\begin{tabular}{|c|c|c|c|c|c|}
\hline $2012 / 13$ & 2013/14 & 2014/15 & 2015/16 & 2016/17 & $2017 / 18$ \\
\hline $\begin{array}{l}\text { - Rail Rolling Stock } \\
\text { - Steel Power Pylons and } \\
\text { Substation Structures } \\
\text { - Bus Bodies } \\
\text { - Canned/Processed } \\
\text { Vegetables } \\
\text { - Textile, Clothing, Leather } \\
\text { and Footwear Sector } \\
\text { - Pharmaceuticals } \\
\text { - Solar Water Heater } \\
\text { Components } \\
\text { - Set-top Boxes } \\
\text { - Furniture Products }\end{array}$ & $\begin{array}{l}\text { - Electrical and } \\
\text { Power Cables, } \\
\text { - Valves } \\
\text { Products and } \\
\text { Actuators }\end{array}$ & $\begin{array}{l}\text { - Working } \\
\text { Vessels (Boats) } \\
\text { - Residential } \\
\text { Electricity and } \\
\text { Water* Meters }\end{array}$ & $\begin{array}{l}\text { - Steel } \\
\text { Conveyance } \\
\text { Pipes } \\
\text { - Transformers } \\
\text { and Shunt } \\
\text { Reactors }\end{array}$ & $\begin{array}{l}\text { - Rail-Signalling } \\
\text { System and } \\
\text { Components } \\
\text { - Wheelie bins } \\
\text { - Fire Engine/Truck } \\
\text { - Steel Products } \\
\text { and Components } \\
\text { for construction }\end{array}$ & $\begin{array}{l}\text { - Rail Perway } \\
\text { (Track) } \\
\text { - Pumps \& } \\
\text { Medium Voltage } \\
\text { Motors } \\
\text { 2019/20 } \\
\text { - Plastic Pipes } \\
\text { - Bulk Material } \\
\text { Handling } \\
\text { - Lead Acid } \\
\text { Batteries } \\
\text { - MV Switchgear }\end{array}$ \\
\hline
\end{tabular}

Figure 2. Products designated for local production [33].

The DTI, in conjunction with National Treasury, issued a number of instructions since 2012 to designate various sectors for local production and content with the aim and intent to promote local industrial development, targeted demand-driven skills development and employment creation [30]. In particular, with regards to transport related manufacturing, the following targets for local content was set by the DTI:

- Buses (Bus Body) 80\%

- Rail Rolling Stock 65\%

- Rail Signalling $65 \%$

- Rail Signalling Components $40-100 \%$

- Rail Permanent Way 90\%

- Rails and rail joints $100 \%$

- Ballasts $100 \%$

- Ballastless $100 \%$

- Turnouts/switches and crossings $100 \%$

- Railway sleepers $100 \%$

- $\quad$ Rail fastening and accessories $100 \%$

- Railway maintenance of way plant \& equipment $70 \%$

- Assembly and testing of fully build units $100 \%$ [33].

In 2020, the Minister of Finance made the Draft Public Procurement Bill available. This Bill aims to "regulate public procurement; to prescribe a framework for procurement policy envisaged in Section 217(3) of the Constitution; and to provide for matters connected 
therewith" [34]. The primary objectives of the intended Act are, inter alia, with due regard to Section 217 of the Constitution, to develop economic capacity in South Africa through the provision of opportunities for local suppliers to participate in procurement.

\subsection{South African Progress towards Green/Sustainable Transport}

It is vital to note that the current South African transportation system is still heavily dependent on so-called "non-renewable" energy sources such as coal, which makes the country vulnerable to the imminent shortage of such non-renewable resources. Although the country has made progress with the promulgation of various "green" policies towards supporting the global Sustainable Development Goals (SDG's), while also aiming to provide in the increasing needs of the public transport commuters. Environmental sustainability became a key performance indicator in investment decisions and as such decisions around investments in infrastructure to support economic efficiency and that promote energy efficiency by minimising the consumption of resources (especially non-renewable) are favoured. Investments in infrastructure where the development and maintenance of the infrastructure are unsustainable and are thus avoided [3].

In the Department of Transport Draft Revised White Paper on National Transport Policy of 2017, the Government proclaims to be committed to "make responsible choices and minimise unnecessary travel, although it will not take steps to cut fuel usage in a manner that harms the economy. However, the Government will encourage the use of fuel-efficient modes of transport, cleaner fuels and green technologies in transport" [3].

However, the other side of the coin in terms of employment sustainability should also be kept in mind. A recently completed Mitigation Potential Analysis (MPA) for South Africa by the National Department of Environment Affairs (DEA) intended to identify those priority mitigation measures, which will significantly contribute towards the reduction of greenhouse gas emissions. One such mitigation, when considering both the scope of mitigation of emissions as well as the related economic and social impacts, is the shift of freight transport, especially heavy and long-haul freight, "from road to rail" [35]. This modal shift was also promulgated by the DoT as part of its National Transport Policy framework [2].

The DEA has however also raised a concern regarding the possible job losses as a result of the movement of freight from road to rail, primarily as rail freight required less trains to move large volumes over long distances, and as such would therefore be less labour intensive. The DEA research was thus also aimed at investigating and gaining insight into the economic impact and ripple effect of the impact on creating job opportunities, decreasing unemployment and, more broadly, on the entire economy [35].

\subsection{Current Transport Realities in South Africa}

Public transport systems of developing countries leave much to be desired, and South Africa is no exception, as it is faced with many large systemic challenges that need to be resolved. The National Department of Transport is the custodian and implementing agency of the National Land Transport Act (No. 5 of 2009) [24]. The main principle of the Act and the main driving policy, the Public Transport Strategy and Action Plan, 2007, is to "integrate land transport planning" with the previously discussed 3-sphere governmental development and land-use planning processes, especially with a focus on the "transport component of the integrated development plan of the municipality" [36].

The National Transport Master Plan 2050, also under the stewardship of the national Department of Transport, aims to guarantee that "the transport systems in the country are accessible to all and that the spatial divisions of the past are eradicated by the provision of alternative modes of transport to persons who do not own cars such as a well-integrated public transport system" [2]. This also confirms the aim to improve transport as part of the rural development goals by the prioritising of public transport systems in rural areas [2] Box 1 below provides some examples of the current transport realities in South Africa. 
Box 1. Current transport realities in South Africa.

The current realities of transport in South Africa are:

- Public transport- “Non-integrated transport planning across various modes has resulted in modes that are not sufficiently customer-focused and that are inefficient and have poor levels of reliability, predictability, comfort and safety'. This is preventing South Africa from competing in the global market and is blocking potential international investment to support the economic growth" [36].

- Infrastructure- “The road infrastructure in rural areas was neglected for a number of decades; this is possibly a result of the funding issues evident for the transport sector and having to compete with various other sectors" [36].

- Urban migration- “The apartheid legacy of South Africa also plays a large role in the spatial problems currently evident in South Africa. The spatial divides are a large contributor to the poor state of the road infrastructure in rural areas" [36].

Even before the onset of the COVID-19 pandemic, current transport planning needed to be agile and able to adopt to higher levels of change, including a rethink of the use of innovative technology as well as the design of alternative strategies towards addressing the requirements of transport demand and supply. Such a flexible transport structure with the aptitude to identify and plan for alternatives when a chosen route of course becomes unusable, is vital towards creating a resilient and agile transport system. According to the DoT, " ... an approach, where incremental and fundamental changes are compatible depending on the specific situation to solve, will result in a more resilient transport system. In deciding when to act, it is better to anticipate this need for change and to act early rather than wait for events to force change. Forward-thinking will require a shift away from piecemeal action to more planned and integrated approaches, including early action whenever possible" [2].

The final challenge towards improving social, economic, and environmental sustainability within the public transport industry within the South African context relates to the issue of diverse role players involved in the life cycle (design, planning, implementation, operation, and maintenance) of public transport systems [37]. These entities may be a mixture of global, national, and local public and private companies, some railway-focused, whilst others operate across various industry sectors, and it appears that they are working in isolation rather than operating in an integrated manner. This presents a major challenge regarding improving the transfer of skills and sustaining the new SMMEs beyond the involvement of the "parent company" who subcontracted them initially. When considering such challenges from a broader systemic view, such noncommunication and co-operation could have a detrimental effect on the design of transport and better cities in the absence of a holistic approach [38].

\subsection{Proposed Policy in South Africa}

When considering a new sustainable transport approach, so-called "low-carbon modes of transportation" should be a priority in the design of urban transport systems, by considering the use of more fuel-efficient transport option, including Bus Rapid Transit (BRT) systems, complemented by trains and nonmotorized transport (NMT), where possible [3]. In aiming to address walking and cycling as an alternative, healthy, and more cost-effective transport mode, the focus should be on ensuring the safety of commuters and the provision of sufficient road and pavement infrastructure [38].

In the same vein, the revitalisation of long-distance transportation infrastructure by means of upgrading of existing and introduction of new long-distance trains with lower energy intensity as an alternative to road transport by motorcar and bus should be considered. Such planning should define the applicability of solutions based on cost-benefit calculations over the minimum distance threshold for the proposed transport infrastructure as well as the degree to which the negative impact on biodiversity and emissions can be reduced in the life cycle (design, construction, or operation) of such long-distance transport systems and supporting infrastructure [3]. 
In line with these expectations, the objectives of the Green Transport Strategy (GTS) include:

- "Enabling the transport sector to contribute its fair share to the national effort to combat climate change in a balanced fashion, taking into account the DoT and the sector's primary responsibility of promoting the development of the efficient integrated transport systems to enable sustainable socio-economic development;

- Promoting behavioural changes towards sustainable mobility alternatives through information, education and awareness raising;

- Engaging the low carbon transition of the sector, to assist with the aligning and developing of policies which promote energy efficiency and emission control measures in all transport modes;

- Minimizing the adverse effects of transport activities on the environment, and

- Facilitating the sector's just transition to climate resilient transport system and infrastructure" [39].

\subsection{Sustained Employment and Capacity}

The SA government launched the New Growth Path (NGP) in response to the 2008 economic downturn, aimed at creating five million new jobs by 2020 , including 300,000 jobs in the green economy [36] with 80,000 in manufacturing and the rest in construction and maintenance of "environmentally friendly infrastructure" [26], which was estimated to create 400,000 jobs by 2030 . The NGP is built on two strategies. Firstly, it seeks to (1) "deepen domestic and regional markets by growing employment, increasing incomes and other measures to improve equity and income distribution" [36]. Secondly, it seeks to (2) "widen the market for South African goods and services through a stronger focus on exports to the region and other rapidly growing economies" [24]. In addition, skills development in all economic sectors to complement the infrastructure investment was also included in the NGP [36].

The Industrial Action Policy Action Plan (IPAP) 2017/18-2019/20 was launched in May 2017 and aimed at increasing the impact of state interventions towards industrial development support and the reindustrialisation of South Africa. This includes greater local participation in providing for manufactured products through public and private sector procurement avenues and local supplier development [24]. A crucial aspect of Local Content 2017 regulations confirms the appointment of the South African Bureau of Standards as the verification agency for Local Content in SA [33].

\subsection{Supplier Development}

Various studies and reports highlight the current challenges in terms of the availability of technical and civil engineering skills required to provide adequate service delivery in infrastructure and transportation, especially at the municipal level [30]. Different studies reveal different findings. The ILO claims that "the community-based work program has created 140,000 jobs of which 19,000 were sustainable with a financial input of R85 million. There is a problem with low-skilled labour-intensive jobs for public works because government can't legitimately build underpaid slave labour programs. Training education and prospective higher skilled employment needs to be integrated in the public works programs. Monitoring and evaluation has so far not been an integral part of the NPWP" [26].

This provides postschool education and training institutions with opportunities to address the skills shortage by supporting matriculants and graduates into the civil engineering and construction field. To ensure appropriate training content, adequate levels of skills development and targeted training, through job creation programmes that focus on technology solutions to construction and maintenance of infrastructure, partnerships between the state, industry, and tertiary training institutions became vital [40].

As previously discussed, the SA railway industry is dominated by major state-owned infrastructure and a few privately owned companies who operate on the railway lines. 
Opportunities for self-employment or SMMEs are extremely limited in terms of operational ownership. SMMEs struggle to implement required environmental practices and to develop their own internal environmental capabilities. To do so, it became somewhat of a norm to see collaboration between small scale suppliers and larger companies (such as construction entities) in terms of various legal requirements, including environmental matters [41]. The railway industry also provides opportunities to SMMEs in the form of:

- Engineering support and maintenance

- Infrastructure installation and maintenance

- Manufacturing of engineering and electrical parts, ICT, and other technical requirements, PPE, clearing materials, building materials, etc.

- Support services such as security, clearing, catering, etc. [23].

Research revealed the following three success stories, which are briefly discussed in Table 4 below:

Table 4. Current railway capacitation examples.

\begin{tabular}{|c|c|}
\hline Entity & Successes \\
\hline $\begin{array}{l}\text { Alstom-Gibela } \\
\text { joint-venture }\end{array}$ & $\begin{array}{l}\text { On } 25 \text { October 2018, the Alstom-led Gibela joint-venture unveiled the largest, most advanced, and the first of } \\
\text { its kind train manufacturing centre in Africa. "The 53,000 } \mathrm{m}^{2} \text { site in Dunnottar, east of Johannesburg in South } \\
\text { Africa was constructed over a period of } 22 \text { months or } 2.5 \text { million hours" [42]. In addition to being a } \\
\text { world-class manufacturing facility with the latest technological innovations, the manufacturing plant also } \\
\text { contains an industry-specific and well-tailored training centre supporting the continued transfer of new } \\
\text { rail-related skills to Gibela's employees and local suppliers [43]. }\end{array}$ \\
\hline Transnet & $\begin{array}{l}\text { As part of the Integrated Supply Chain Management (iSCM) strategy, Transnet implemented a Supplier } \\
\text { Development Programme, which provides for skills development, job creation and preservation, intellectual } \\
\text { property transfer, and the localisation of supply, and ultimately, industrialisation through contractually } \\
\text { obligated supplier development plans [44]. }\end{array}$ \\
\hline $\begin{array}{l}\text { Naledi } \\
\text { Inhlanganiso } \\
\text { Group }\end{array}$ & $\begin{array}{l}\text { As one of the largest foundries in SA, this } 100 \% \text { black-owned group is also majority women-owned. } \\
\text { Established in } 2013 \text { in the steel and iron manufacturing industry the company is driving transformation and } \\
\text { industrialisation through investment in plant, peoples, and products support Government IPAP and NDP } \\
\text { objectives in localisation, reindustrialisation, and transformation [45]. }\end{array}$ \\
\hline
\end{tabular}

\section{Concluding Remarks}

The three pillars of sustainable development-economic, social, and environmentalare profoundly interlinked [36]. Revitalisation and expansion of the transport sector may potentially have an increasing impact on jobs, employment, as well as land-use and environmental factors such as water and air quality and biodiversity.

Many of the current SA sustainability goals are scattered across various sectorial plans. It is however vital to keep in mind that any public funds expenditure to a company beyond our border will not benefit the goals of improving the country's GDP, employment levels, or inequality targets, and therefore, the increased use and development of local suppliers and manufacturers should be a priority. This includes, among others:

- Construction of rail infrastructure

- Manufacturers of rail vehicles

- Manufacturers of road vehicles (both for freight and passenger vehicles)

- Industries which engage in the backward linkages of these industries, such as the energy industry, where there are many new developments underway [35].

The national rail infrastructure is characterised by bottlenecks, as well as non-native freight on road due to rail inefficiencies. These stem from a historical lack of investment in infrastructure, lack of maintenance, and insufficient skills, all of which drive freight to road. Sectors such as agriculture have limited access to rail capacity which, in turn, hampers exports $[46,47]$. Transnet is collaborating with specific sectors to develop improved export channels, from farm to offshore customer, which provides opportunities for international collaboration. Further, the rail service provider has announced the use of concessions on 
branch lines with the aim of improving efficiencies, which could facilitate opportunities for sector-specific rail-based service provision [44].

The rail industry constitutes a specialised work setting that requires specific and sometimes scarce skills to support research, development, design, investment, construction and manufacturing, marketing, operations and maintenance, and corporate strategy. The impact of the industry's decline over several decades resulted in it losing its ability to develop and retain skills. One of the challenges to its revitalisation is therefore to restore that ability [2]. It is important to note that major infrastructure upgrading projects were planned and initiated, which provides opportunities for smaller entities, such as self-employed persons, to gain access to the industry [2].

It is essential for governments to verify that the objectives of procurement are holistically achieved, whether these are value for money objectives in the traditional sense of cost-benefit and profit, or broader policy objectives such as sustainable development $[1,48]$.

This study is limited in the sense that it is based on documentary analysis only, which can be further enhanced by making us of other research methods both qualitative and quantitative (interviews, surveys, focus groups, etc.) to add to the current findings. The study is also only focused on the South African railway transport sector, which could be expanded into further research into the experiences of locally owned suppliers and manufacturers as well as other down-stream beneficiaries that would add value to improve future planning, monitoring, and evaluation of public procurement as a catalyst for socio-economic sustainability within the Green Transport sector. In addition, further research aimed at addressing gaps identified and gaining additional evidence from transport endeavours in the Global South would enable policy makers and strategic planners to be better informed and more proactive in designing solutions for the future.

Author Contributions: D.F.: conceptualization, formal analysis, writing of draft preparation, and project administration. C.M.: methodology, formal analysis, review, and editing. All authors have read and agreed to the published version of the manuscript.

Funding: This research received no external funding.

Institutional Review Board Statement: Not applicable.

Informed Consent Statement: Not applicable.

Data Availability Statement: Not applicable.

Conflicts of Interest: The authors declare no conflict of interest.

\section{References}

1. Organisation for Economic Co-Operation and Development (OECD). Public Procurement for Sustainable and Inclusive Growth; Organisation for Economic Co-Operation and Development (OECD): Paris, France, 2012. Available online: https: / /www.oecd. org/gov/ethics/Public-Procurement-for\%20Sustainable-and-Inclusive-Growth_Brochure.pdf (accessed on 15 May 2021).

2. Department of Transport. Green Transport Strategy for South Africa: (2018-2050); Department of Transport: Pretoria, South Africa, 2018. Available online: https:/ / www.transport.gov.za/documents/11623/89294/Green_Transport_Strategy_2018_205 0_onlineversion.pdf/71e19f1d-259e-4c55-9b27-30db418f105a (accessed on 17 May 2021).

3. Department of Transport. Draft Revised White Paper on National Transport Policy; Department of Transport: Pretoria, South Africa, 2017. Available online: https:/ / www.gov.za/sites/default/files/gcis_document/201803/nationalwhitepapertransportdraft_1. pdf (accessed on 17 May 2021).

4. Duquesne University. Systematic vs. Scoping vs. Integrative Review. Retrieved from Duquesne University Gumberg Library. Available online: https:/ / guides.library.duq.edu/c.php?g=1055475\&p=7725920 (accessed on 1 October 2021).

5. Auriacombe, C.J. Towards the construction of unobtrusive research techniques: Critical considerations when conducting a literature analysis. Afr. J. Public Aff. 2016, 9, 1-14.

6. Whittemore, R.; Knafl, K. The integrative review: Updated methodology. J. Adv. Nurs. 2005, 52, 546-553. [CrossRef] [PubMed]

7. SAGE. Document Analysis. In The SAGE Encyclopaedia of Educational Research, Measurement, and Evaluation; Frey, B., Ed.; SAGE Publications, Inc.: Thousand Oaks, CA, USA, 2018; Volume 1-4, p. 2018. [CrossRef]

8. Bowen, G.A. Document Analysis as a Qualitative Research Method. Qual. Res. J. 2009, 9, 27-40. [CrossRef]

9. Van Lierop, D.; Badami, M.G.; El-Geneidy, A.M. What influences satisfaction and loyalty in public transport? A review of the literature. Transp. Rev. 2018, 38, 52-72. [CrossRef] 
10. Ahmed, J.U. Documentary research method: New dimensions. Indus J. Manag. Soc. Sci. 2010, 4, 1-14.

11. Wangai, A.W.; Rohacs, D.; Boros, A. Supporting the Sustainable Development of Railway Transport in Developing Countries. Sustainability 2020, 12, 3572. [CrossRef]

12. Development Bank of Southern Africa (DBSA). How the Current State of Public Transport Impacts Employment in South Africa. Available online: https://www.dbsa.org/article/how-current-state-public-transport-impacts-employment-south-africa (accessed on 7 August 2021).

13. UIC. Railways and Green Growth: Why Investing in Railways Leads to a Better Future; UIC (International Union of Railways), Fundamental Values Department: Paris, France, 2015.

14. Thomas, R. Urban Goods Movement; Routledge: London, UK, 1992.

15. Mead, L. The Road to Sustainable Transport. International Institute for Sustainable Development; IISD Earth Negotiations Bulletin: Winnipeg, MB, Canada, 2021. Available online: https:/ / www.iisd.org/system/files/2021-05/still-one-earth-sustainable-transport. pdf (accessed on 7 August 2021).

16. United Nations Environment Programme. Towards a Green Economy: Pathways to Sustainable Development and Poverty Eradication; United Nations Environment Programme: Nairobi, Kenya, 2011. Available online: www.unep.org/greeneconomy (accessed on 7 August 2021).

17. DBSA. How Green Transport Can Be a Catalyst for Economic Development and Growth. Available online: https://www.dbsa. org/article/how-green-transport-can-be-catalyst-economic-development-and-growth (accessed on 7 August 2021).

18. Ogryzek, M.; Adamska-Kmieć, D.; Klimach, A. Sustainable Transport: An Efficient Transportation Network-Case Study. Sustainability 2020, 12, 8274. [CrossRef]

19. ARUP. Transformative Rail; ARUP: London, UK, 2020.

20. Cohen, B.; Cowie, A.; Babiker, M.; Leip, A.; Smith, P. Co-benefits and trade-offs of climate change mitigation actions and the Sustainable Development Goals. Sustain. Prod. Consum. 2021, 26, 805-813. [CrossRef]

21. Dulac, J. Global Land Transport Infrastructure Requirements: Estimating Road and Railway Infrastructure Capacity and Costs to 2050; International Energy Agency: Paris, France, 2013.

22. StatsSA. Sustainable Development Goals: Country Report 2019; Statistics South Africa: Pretoria, South Africa, 2019.

23. South African Government. National Railway Safety Regulator Act No.16 of 2002, as Amended; South African Government: Pretoria, South Africa, 2009. Available online: http://rsr.org.za/wp-content/uploads/2014/09/RSR-Act.pdf (accessed on 14 August 2021).

24. CFM. CFM Home. Retrieved from CFM. Portos e Caminhos de Ferro de Moçambique; Department of Planning, Monitoring and Evaluation: Pretoria, South Africa, 2018.

25. DPME. Towards a 25 Year Review; Department of Planning, Monitoring and Evaluation: Pretoria, South Africa, 2019. Available online: https:/ / www.dpme.gov.za/news/SiteAssets/Pages/25-Year-Review-launch/Towards\%20A\%2025\%20Year\%20Review. pdf (accessed on 7 June 2021).

26. Rennkamp, B. Sustainable Development Planning in South Africa: A Case of Over-Strategizing? Media Africa, University of Cape Town, Energy Research Centre: Cape Town, South Africa, 2013; pp. 1-15. Available online: https://media.africaportal.org/ documents /13-Rennkamp-Sustainable-Development_Planning.pdf (accessed on 4 August 2021).

27. Bolton, P. Public Procurement as a Tool to Drive Innovation in South Africa. Potchefstroom Electron. Law J./Potchefstroomse Elektron. Regsblad 2016, 19, 1-35. [CrossRef]

28. National Treasury. Economic Transformation, Inclusive Growth, and Competitiveness: Towards an Economic Strategy for South Africa; Economic Policy, National Treasury: Pretoria, South Africa, 2019. Available online: http:/ /www.treasury.gov.za/comm_media/ press / 2019/Towards\%20an\%20Economic\%20Strategy\%20for\%20SA.pdf (accessed on 4 August 2021).

29. South African Government. South African Government Documents-Constitution of the Republic of South Africa, 10 December 1996; South African Government: Pretoria, South Africa, 1996. Available online: https://www.gov.za/documents/constitutionrepublic-south-africa-1996 (accessed on 26 July 2021).

30. National Treasury. Leveraging Local Public Procurement; Portfolio Committee on Trade and Industry (O-CPO): Pretoria, South Africa, 2017.

31. National Treasury. Invitation and Evaluation of Bids Based on A Stipulated Minimum. Threshold for Local Production and Content for the Rail Rolling Stock Sector; National Treasury: Pretoria, South Africa, 2012.

32. South African Government. Preferential Procurement Policy Framework Act, 2000: Preferential Procurement Regulations, 2017; National Treasury: Pretoria, South Africa, 2017.

33. South African Government. Local Content Policy \& Designation: Measures to Ensure Compliance and Verification-Presentation to the Portfolio Committee on Trade and Industry, 11 March 2020; The Department of Trade and Industry: Pretoria, South Africa. Available online: http://www.thedtic.gov.za/sectors-and-services-2/industrial-development/industrial-procurement/ (accessed on 4 August 2021).

34. National Treasury. Draft Public Procurement Bill; National Treasury: Pretoria, South Africa, 2020.

35. Department of Environmental Affairs. Freight Shift from Road to Rail; Department of Environmental Affairs: Pretoria, South Africa, 2015.

36. Transport Education Training Authority. TETA Annual Report 2019/20. Randburg: Transport Education and Training Authority; Transport Education Training Authority: Randburg, South Africa, 2020. Available online: https://www.teta.org.za/documents/ TETA\%20Annual\%20Report\%202019-2020.pdf (accessed on 4 February 2021). 
37. Mthimkulu, N. Southern African solutions to public transport challenges. In Proceedings of the 36th Southern African Transport Conference (SATC 2017), Pretoria, South Africa, 10-13 July 2017; pp. 811-817.

38. Guntersweiler, C.; Hammacher, H.; Bentz, E.; Hong, H.; Chan, E.; Reed, B.; Gebert, T.; Kocan, D.; Smart, D.; Ternisien, B.; et al. IMIA Working Group Paper 102-Rolling Stock. In Proceedings of the IMIA Annual Conference 2017, Munich, Germany, 2-6 September 2017; pp. 4-67.

39. Morapedi, K.; Makhari, M. National Transport Master Plan (NATMAP) 2050. In Proceedings of the 36th Southern African Transport Conference (SATC 2017), Pretoria, South Africa, 10-13 July 2017; pp. 778-787.

40. SA Venues. SA Steam Trains. 1999. Available online: https://www.sa-venues.com/activities/steam-trains.php (accessed on 24 August 2021).

41. Department of Forestry, Fisheries and the Environment. Non-Motorized Transport—South Africa; Department of Forestry, Fisheries and The Environment: Pretoria, South Africa, 2021. Available online: https:/ / www.environment.gov.za/projectsprogrammes/ nonmotorizedtransport_southafrica (accessed on 15 May 2021).

42. Gibela. The Socio-Economic Impact of Gibela; Railways Africa: Midrand, South Africa, 2020; pp. 1-48. Available online: https: / www.railwaysafrica.com/assets/news/how-gibela-is-helping-south-africa-grow / The-Socio-economic-Impact-ofGibela-report-August-2020.pdf (accessed on 14 August 2021).

43. Alstom. Alstom's Gibela Joint Venture Opens Africa's Largest Train Manufacturing Facility in Dunnottar, South Africa. 25 October 2018. Available online: https:/ / www.alstom.com/press-releases-news/2018/10/alstoms-gibela-joint-venture-opensafricas-largest-train-manufacturing (accessed on 14 August 2021).

44. Transnet. Transnet Local Public Procurement Feedback: Portfolio Committee on Trade and Industry—March 2017; Transnet: Johannesburg, South Africa, 2017.

45. Naledi. Naledi Inhlanganiso Group Presentation to Portfolio Committee 24 March 2017; Naledi Inhlanganiso Group: Benoni, South Africa, 2017.

46. Pham, T.; Pham, H. Improving green performance of construction projects through supply chain integration: The role of environmental knowledge. Sustain. Prod. Consum. 2021, 26, 933-942. [CrossRef]

47. Gain Group. Sector Study: Logistics South Africa. A Study Commissioned by the Netherlands Enterprise Agency; Gain Group (Pty) Ltd.: Stellenbosch, South Africa, 2020. Available online: https:/ /www.rvo.nl/sites/default/files/2020/08/sector-study-logistics-insouth-africa.pdf (accessed on 4 August 2021).

48. United Nations (UN). Transport: Sustainable Development Goals; United Nations: New York, NY, USA, 2010. Available online: https://sustainabledevelopment.un.org/dsd_aofw_ni/ni_pdfs/NationalReports/south_africa/Transport.pdf (accessed on 23 July 2021). 